\title{
Perancangan Lanskap Sekolah Menuju Peningkatan Penerapan Program Adiwiyata SMKN 63
}

\section{(The Design of School Landscape Towards the Improvement of Application Adiwiyata Program SMKN 63)}

\author{
Silia Yuslim*, Etty Indrawati, Ida Bagus Rabindra, Olivia Seanders \\ Program Studi Arsitektur Lanskap, Fakultas Arsitektur Laskap dan Teknologi Lingkungan, Universitas Trisakti \\ Jl. Kyai Tapa No.1, RT 6/RW 16, Grogol, Grogol Petamburan, Jakarta Barat, Jakarta 11440. \\ *Penulis Korespondensi: siliayuslim@trisakti.ac.id \\ Diterima Juni 2020/Disetujui Februari 2021
}

\begin{abstract}
ABSTRAK
Program Studi Lanskap dan Pertamanan (LDP), salah satu program studi di SMKN 63 Jagakarsa, Jakarta Selatan membutuhkan pembinaan terkait materi pembelajaran pembuatan rancangan (design) lanskap. Tujuan dari pemberian materi perancangan lanskap bagi warga sekolah (guru dan siswa), adalah meningkatkan wawasan dan keterampilan pembuatan rancangan lanskap, untuk mengoptimakan fungsi dan keindahan ruang luar sekolah. Ini mendukung prilaku berbudaya lingkungan yang digalakkan program Adiwiyata. Kegiatan pengabdian berupa sosialisasi dan pelatihan agar warga sekolah dapat merancang lanskap secara mandiri serta penyebaran kuesioner untuk mengukur tingkat ketercapaian sosialisasi dan pelatihan yang dilakukan. Lahan kasus untuk dirancang adalah taman sudut di halaman depan SMKN 63. Hasil kegiatan memperlihatkan bahwa persepsi peserta masuk dalam kategori setuju hingga sangat setuju terhadap nilai manfaat materi pengabdian. Peserta sangat antusias dan aktif. Kreatifitas dan pembuatan rancangan masih perlu bimbingan. Evaluasi di bulan berikutnya, mempelihatkan tindak lanjut dari hasil rancangan yang dihasilkan. Antusias ini mendorong adanya kesepakatan kerja sama antara pihak SMKN 63 dan tim pengabdian dari Jurusan Arsitektur Lanskap, Fakultas Arsitektur Laskap dan Teknologi Lingkungan, Universitas Trisakti untuk membina warga sekolah secara berkelanjutan.
\end{abstract}

Kata kunci: perancangan lanskap sekolah, program adiwiyata, SMKN 63

\begin{abstract}
The Study Program of Landscaping and Gardening (Program Studi Lanskap dan Pertamanan (LDP)), one of the study programs at SMKN 63 Jagakarsa, South Jakarta, needs guidance related to learning materials of landscape design. The purpose of providing landscape design materials for school members (teachers and students) is to increase the knowledge and skills of making landscape designs and optimize the function and beauty of the school's out space. It supports the behavior of the environmental awareness that the Adiwiyata program promotes. Community service activities in the form of socialization and training so that school members can design the landscape independently and distribute questionnaires to measure the level of achievement of the socialization and training were carried out. The case area to be designed is a corner garden in the front yard of SMKN 63. The activity results show that the participants' perceptions fall into the category of agreeing to strongly agree on the value of the benefits of the service material. Participants were very enthusiastic and active. Creativity and design making still need guidance. Evaluation in the following month shows the follow-up of the resulting design. This enthusiasm led to a cooperation agreement between SMKN 63 and a community service team from the Landscape Architecture Department, Faculty of Laskap Architecture and Environmental Technology, Trisakti University to foster school residents sustainably.
\end{abstract}

Keywords: adiwiyata program, SMKN 63, the design of school landscape

\section{PENDAHULUAN}

Program Pengabdian kepada Masyarakat (PKM) ini dilaksanakan berdasarkan penjajagan kerja sama antara Jurusan Arsitektur Lanskap, Fakultas Arsitektur Laskap dan Teknologi Ling- kungan, Universitas Trisakti dengan SMKN 63. Program PKM yang akan dilaksanakan terkait dengan pembinaan sekolah untuk meningkatkan pelaksanaan program Adiwiyata di sekolahsekolah. Program sekolah Adiwiyata yang bertujuan menanamkan kecintaan warga sekolah 
pada lingkungan hidupnya, dengan menanamkan sikap dan perilaku yang peduli dan berbudaya lingkungan (Widiyaningrum 2015). Sejalan dengan hasil penjajagan yang dilakukan, bahwa salah satu pogram studi SMKN 63, yaitu program studi Lanskap Dan Pertamanan (LDPP) membutuhkan pembinaan, terkait materi pembelajaran tentang aktivitas perancangan lanskap. Materi tersebut sangat diperlukan, karena dengan penguasaan terhadap materi tersebut, warga sekolah dapat mengelola dan meningkatkan kualitas ruang luar sekolah sebagai area pembelajaran yang lebih bermanfaat dan berkelanjutan.

Sebagai salah satu sekolah di antara 16 sekolah di wilayah Jakarta Selatan yang telah mendapat penghargaan Sekolah Adiwiyata tingkat Kota Administrasi Jakarta Selatan tahun 2019 (KIP JS 2019), SMKN 63 telah menerapkan komponen Program Adiwiyata. Komponen tersebut tercantum dalam Peraturan Menteri Lingkungan Hidup Republik Indonesia No. 05 tahun 2013 tentang Pedoman Pelaksanaan Program Adiwiyata. Aspek-aspek yang terkait dengan komponen program Adiwiyata, meliputi aspek kebijakan sekolah yang berwawasan lingkungan, aspek kurikulum sekolah berbasis lingkungan, aspek kegiatan sekolah berbasis partisipatif, dan aspek pengelolaan sarana dan prasarana pendukung sekolah yang ramah lingkungan. Menurut Kamarullah et al. (2019), pemberian penghargaan sekolah Adiwiyata pada sekolah yang secara serius memperlihatkan kepeduliannya terhadap lingkungan hidup merupakan salah satu langkah untuk memotivasi. Penghargaan ini telah memacu SMKN 63 untuk selalu meningkatkan dan menyempurnakan kepedulian warganya terhadap lingkungan. Menurut Krajhanz (2010) perwujudan perilaku peduli lingkungan dapat dijabarkan melalui tiga aspek, yaitu tingkat pengetahuan, sikap, dan perilaku. Salah satu upaya untuk mencapainya adalah dengan meningkatkan kualitas ruang luar sekolah menjadi lebih fungsional dan indah. Ini sejalan dengan salah satu indikator sekolah Adiwiyata, yang menurut Hidayati et al. (2020), adalah dengan melakukan pengembangan dan pengelolaan sarana pendukung sekolah untuk Pendidikan Lingkungan Hidup (PLH), peningkatan upaya penghematan energi, air, pengembangan sistem pengelolaan sampah, peningkatan kualitas pengelolaan lingkungan di dalam dan di luar kawasan sekolah, dan pengembangan apotik hidup serta taman sekolah.
Menurut Apriliyadi (2019), secara garis besar SMKN 63 memiliki sarana dan prasarana yang cukup lengkap dalam mendukung pembelajaran 534 siswa yang tersebar dalam empat program studi keahlian, yaitu Agribisnis Tanaman Pangan dan Hortikultura (ATPH), Agribisnis Perbenihan dan Kultur Jaringan (APKJ), Lanskap dan Pertamanan (LDP), dan Agribisnis Pengolahan Hasil Pertanian (APHP). Sarana dan prasarana ruang luar yang tersedia untuk pendukung proses pembelajaran, di antaranya adalah lahan praktik siswa seluas 3,5 ha yang berupa lahan darat dan sawah serta lapangan volly, bulu tangkis, tenis meja, dan bola basket. Sekolah ini juga memiliki greenhouse aeroponik dan hidroponik, greenhouse biasa, unit produksi kultur jaringan serta koleksi tanaman perkebunan dan tanaman obat. Sarana dan prasarana ini sangat mendukung proses pembelajaran terutama untuk tiga program studi yang ada, namun, untuk program studi Lanskap dan Pertamanan (LDP) keberadaan sarana dan prasarana yang ada hanya mendukung untuk proses pengadaan material tanaman. Mengacu pada landasaan pemikiran ini, maka kondisi sarana dan prasarana serta lingkungan SMKN 63 dapat lebih ditingkatkan melalui materi-materi pembelajaran yang disempurnakan.

Beberapa penelitian juga memperkuat pemikiran tersebut. Sidauruk et al. (2013), mengungkapkan bahwa pendidikan berbasis lingkungan pada dasarnya adalah menggunakan lingkungan sebagai basis orientasi pendidikan. Dua peran dasar yang dimiliki lingkungan dalam pendidikan, yaitu sebagai pemberi pemelajaran pada anak didik (educative environment); dan sebagai wadah yang harus diperbaiki oleh produk pendidikan (better environment by education). Melalui proses pendidikan seluruh aspek lingkungan akan diarahkan menjadi kondisi yang prima dengan standar (baku mutu) yang mampu membawa Negara Indonesia menjadi negara yang besar, aman, dan sejahtera. Selain itu, beberapa penelitian mengungkapkan bahwa kegiatan pembelajaran luar ruangan (outdoor learning process) dapat memberi pengaruh positif terhadap hasil belajar siswa dan dapat meningkatkan rasa cinta terhadap lingkungan (Santiningtyas 2012). Penelitian Safitri et al. (2014) juga mengungkapkan bahwa strategi pembelajaran Outdoor Learning Process (OLP) yang dibantu dengan penggunaan papan klasifikasi, memberikan kemudahan dan pengalaman langsung pada siswa sehingga pembelajaran menjadi lebih bermakna. Puspawati (2009); Nugraha (2017) juga mengungkapkan bahwa 
outdoor learning merupakan alternatif baru untuk peningkatan pengetahuan dan pencapaian kualitas pembelajaran, terutama terhadap materi yang memang akan lebih optimal jika pembelajaran dilaksanakan di luar ruangan. Sementara Widiyaningrum (2015) menyatakan bahwa pembelajaran luar ruangan menciptakan situasi belajar yang monoton menjadi menyenangkan karena adanya kelompok sosial. Melalui pengalaman interaksi sosial yang terbentuk dan interaksi dengan lingkungan sekitar, perkembangan mental siswa terhadap kepedulian dengan sesama dan lingkungan menjadi matang. Bahrudin (2017) mengungkapkan bahwa berbagai aspek terkait sangat berperan dalam mengkondisikan lingkungan sekolah untuk membiasakan perilaku peduli lingkungan dari warga sekolah. Pembiasaan perilaku peduli lingkungan dapat terwujud melalui rancangan ruang luar sekolah yang fungsional dan indah. Ruang luar yang berkualitas menjadikan warga sekolah berupaya untuk menjaga dan memeliharanya. Kebiasaan ini akan membentuk karakter peduli lingkungan warga sekolah, terutama siswa. Pada akhirnya, siswa akan terbiasa untuk menjaga, merawat dan melestarikan lingkungannya. Semua pernyataan tersebut memperlihatkan bahwa melalui peningkatan kualitas fungsi dan keindahan ruang luar yang mendukung pembelajaran di luar ruangan kelas dapat meningkatkan kualitas pembelajaran dan kepedulian terhadap lingkungan sekolah.

Terkait dengan hal tersebut, permasalahan yang terdapat pada SMKN 63 adalah bahwa sarana dan prasarana sudah cukup banyak tersedia, namun belum tertata secara optimal sehingga secara fungsional sarana dan prasarana tersebut belum dapat berfungsi secara maksimal dalam mendukung terlaksananya program Adiwiyata. Ini sejalan dengan kebutuhan akan materi pembelajaran dari program studi LDP yang terkait dengan perancangan lanskap. Oleh sebab itu, program PKM ini akan melakukan sosialisasi dan pelatihan tentang perancangan lanskap, yang meliputi: 1) Tahapan proses perancangan lanskap; 2) Unsur-unsur pembentuk rancangan lanskap; 3) Prinsip perancangan lanskap yang perlu dipertimbangkan; dan 4) Cara menerapkan rancangan lanskap di lapangan. Untuk kasus pelatihan pembuatan rancangan, pihak sekolah menentukan lokasi rancangan di taman sudut yang berada di halaman depan sekolah. Sosialisasi dan pelatihan dilakukan kepada peserta yang terdiri dari guru dan siswa selama dua hari. Hasil pelatihan yang berupa gambar rancangan dari kelompok yang terbaik, disempurnakan oleh tim dan hasilnya diberikan kepada sekolah untuk dokumentasi. Tujuan dari program pengabdian ini adalah meningkatkan wawasan dan keterampilan pembuatan rancangan lanskap, untuk mengoptimakan fungsi dan keindahan ruang luar sekolah. Sehingga, sarana dan prasarana ruang luar menjadi lebih fungsional dan indah serta dapat mendukung peningkatan penerapan program Adiwiyata.

\section{METODE PELAKSANAAN KEGIATAN}

\section{Lokasi, Partisipan, dan Metode Pelaksanaan}

Program PKM ini dilakukan kepada guru dan siswa SMKN 63 di Cipedak, Kecamatan Jagakarsa, Jakarta Selatan dalam periode waktu dari bulan Mei-Agustus 2019. Program ini diawali dengan tahap survei berdasarkan permintaan dari pihak SMKN 63. Survei dilakukan pada bulan Mei 2019. Pada saat survei, dilakukan diskusi dengan beberapa guru dan kepala sekolah untuk merumuskan segala sesuatu yang diharapkan dari pihak sekolah. Hasil dari survei, terwujudlah keinginan pihak SMKN 63 untuk menjalin kerja sama dengan jurusan Arsitektur Lanskap, Universitas Trisakti. Berdasarkan survei juga ditentukanlah bagian ruang luar sekolah yang akan dijadikan lokasi percontohan bagi pembuatan desain dan dirumuskan juga tahapan pelaksanaan program PKM.

Pelaksanaan program PKM dibagi menjadi tiga tahap dan dilaksanakan pada akhir bulan Juli 2019. Tahap pertama sosialisasi, tahap kedua pelatihan, dan tahap ketiga penyebaran kuesioner. Pelaksanaan program PKM, adalah sebagai berikut:

- Sosialisasi tentang materi yang terkait dengan perancangan lanskap. Kegiatan dilakukan pada pukul 09.00-11.30 WIB dengan materi: a) Tahapan proses perancangan lanskap, (Simonds \& Starke 2006) terdiri dari inventtarisasi, analisis, sintesis, perancangan, pelaksanaan dan pemeliharaan; b) Unsurunsur pembentuk rancangan lanskap, (Agrotek Umpar 2012) terdiri dari permukaan tanah, tanaman, perabot taman, perkerasan dan air; c) Prinsip-prinsip perancangan lanskap (Multimedia 2016) terdiri dari kesatuan (unity), keseimbangan (balance), irama (ritme), penekanan (emphasis), kontras, dan proporsi; serta d) Cara menerapkan rancangan lanskap di lapangan. 
Dalam penerapannya, setiap perancang harus memperhatikan kebutuhan dari fasilitas serta sarana dan prasarana ruang luar yang akan dirancang, karena masing-masing memiliki kebutuhan berbeda, yang nantinya akan berpengaruh pada karakteristik ruang yang akan terwujud sesuai dengan fungsi yang harus diperankannya. Kemudian perancang akan mulai merancang dengan menggunakan unsur-unsur pembentuk rancangan lanskap yang ditata dengan memperhatikan prinsipprinsip perancangan lanskap, agar tercipta hasil rancangan yang fungsional, proposional, memberikan kenyamanan dan indah. Semua hal tersebut dapat dihasilkan secara optimal melalui tahapan proses perancangan.

- Pelatihan tentang pembuatan rancangan lanskap, dengan lokasi rancangan: Taman Sudut di halaman depan SMKN 63. Kegiatan ini dilakukan pada pukul 13.00-16.00 WIB. Dalam pelatihan ini, peserta dibagi dalam empat kelompok yang beranggotakan guru dan siswa. Peserta dilatih untuk menggali kebutuhan dari area yang akan dirancang, untuk kemudian diwujudkan dalam gagasan dan dituangkan dalam gambar rancangan. Setelah gambar rancangan selesai, seluruh kelompok mempresentasikannya dan didiskusikan untuk dipilih yang terbaik secara musyawarah.

- Penyebaran kuesioner kuesioner dilakukan untuk mengukur tingkat ketercapaian sosialisasi dan pelatihan yang telah dilaksanakan dan sikap/tanggapan peserta terhadap materi dengan pemberian skor yang menggunakan skala likert.

Sebulan setelah pelaksanaan program PKM, tepatnya akhir bulan Agustus, dilakukanlah evaluasi. Caranya adalah dengan mendatangi kembali SMKN 63 sebagai lokasi tempat penyelenggaraan PKM. Ini dilakukan untuk melihat sejauh mana program yang diberikan mendapatkan tanggapan yang baik dari peserta PKM.

\section{Pengumpulan dan Analisis Data}

Pengumpulan data dilakukan dengan cara pengukuran tingkat ketercapaian sosialisasi dan pelatihan, serta pengukuran sikap peserta terhadap materi sosialisasi dan pelatihan. Pengukuran tingkat ketercapaian sosialisasi dan pelatihan dilakukan dengan menggunakan kuesioner yang skornya ditentukan berdasarkan skala Likert dengan rentang skala penilaian yaitu: Sangat Tidak Setuju $=1$, Tidak Setuju $=2$, Ragu-ragu $=3$, Setuju = 4, dan Sangat Setuju = 5 (Budiaji 2013; Janti 2014), seperti pada Tabel 1. Setelah melakukan observasi dengan menggunakan instrumen pengumpul data kuesioner, dilakukan analisis. Analisis data menurut Amirin (2010) menggunakan analisis proporsi (persentase) atau frekuensi (banyaknya), untuk tiap pertanyaan pada kuesioner. Langkah yang perlu dilakukan:

- Penentuan kriteria penilaian, dapat dilihat pada Tabel 2.

- Perhitungan nilai. Responden pada kegiatan pengabdian ini adalah 20 peserta, yang terdiri dari 5 guru dan 15 siswa. Perhitungan akan dilakukan pada setiap pertanyaan kuesioner berdasarkan banyaknya peserta yang menjawab dengan skor tertentu, yaitu:

$$
\begin{gathered}
\text { Persentase }=\text { Responden / Jumlah total } \\
\text { responden } \times 100 \% \\
\text { Nilai = Kriteria penilaian } \times \text { Frekuensi }
\end{gathered}
$$

Contoh perhitungan presentase penilaian dapat dilihat pada Tabel 3.

- Pengkategorian, dilakukan dengan menentukan kelas interval penilaian (Tabel4), yaitu

Tabel 2 Kriteria penilaian tingkat manfaat yang dirasakan responden

\begin{tabular}{|c|c|c|c|c|c|}
\hline \multirow[b]{2}{*}{ Aspek yang dinilai } & \multicolumn{5}{|c|}{ Kriteria/skala penilaian } \\
\hline & $\begin{array}{l}\text { Sangat tidak } \\
\text { setuju }\end{array}$ & $\begin{array}{l}\text { Tidak } \\
\text { setuju }\end{array}$ & $\begin{array}{l}\text { Ragu- } \\
\text { ragu }\end{array}$ & Setuju & $\begin{array}{l}\text { Sangat } \\
\text { setuju }\end{array}$ \\
\hline $\begin{array}{l}\text { Bermanfaat bagi peningkatan kualitas sarana dan } \\
\text { prasarana ruang luar sekolah (lebih fungsional } \\
\text { dan estetis) } \\
\text { Bermanfaat bagi kegiatan pembelajaran } \\
\text { Bermanfaat bagi pembinaan prilaku berbudaya } \\
\text { lingkungan }\end{array}$ & & & & & \\
\hline
\end{tabular}

\begin{tabular}{lc}
\hline \multicolumn{1}{c}{ Tingkat manfaat } & Nilai \\
\hline Sangat setuju & 5 \\
Setuju & 4 \\
Netral/ragu-ragu & 3 \\
Tidak setuju & 2 \\
Sangat tidak setuju & 1 \\
\hline
\end{tabular}

Tabel 1 Lembar observasi untuk penilaian terhadap tingkat manfaat sosialisasi dan pelatihan 
menurut Syofian et al. (2015), dengan perhitungan:

Wilayah data $=$ Nilai tertinggi - Nilai terendah

Nilai tertinggi $=$ Total responden $\mathrm{x}$ Kriteria penilaian terbesar

Nilai terendah $=$ Total responden $\mathrm{x}$ Kriteria penilaian terkecil

Interval = Wilayah data / Banyaknya kelas

- Pengukuran sikap peserta terhadap materi sosialisasi dan pelatihan menggunakan kuesioner yang skornya ditentukan berdasarkan skala Likert dengan rentang skala penilaian, yaitu Tidak Setuju $=1$, Netral/ragu-ragu $=2$, dan Setuju $=3$. Lembar obsevasi dapat dilihat pada Tabel 5 dan pengkategorian penilaian pada Tabel 6. Lembar observasi dianalisis secara diskriptif untuk melihat sikap peserta dalam diskusi selama proses sosialisasi dan pelatihan.

Tabel 3 Contoh perhitungan persentase dan penilaian

\begin{tabular}{lccc}
\hline \multicolumn{1}{c}{ Pilihan jawaban } & Frekuensi & $\begin{array}{c}\text { Persentase } \\
(\%)\end{array}$ & Nilai \\
\hline Sangat setuju & 6 & 30 & 30 \\
Setuju & 10 & 50 & 40 \\
Netral/ragu-ragu & 0 & 0 & 0 \\
Tidak setuju & 3 & 15 & 6 \\
Sangat tidak setuju & 1 & 5 & 1 \\
\hline Total nilai & & & 77 \\
\hline
\end{tabular}

Tabel 4 Kelas interval untuk pengkategorian tingkat manfaat sosialisasi dan pelatihan

\begin{tabular}{lc}
\hline \multicolumn{1}{c}{ Kategori } & Kelas interval \\
\hline Sangat tidaksetuju & $20-35$ \\
Tidak setuju & $36-51$ \\
Netral/ragu-ragu & $52-67$ \\
Setuju & $68-83$ \\
Sangat setuju & $84-100$ \\
\hline
\end{tabular}

\section{HASIL DAN PEMBAHASAN}

Program PKM ini dilaksanakan di SMKN 63 yang berlokasi di Cipedak, Kecamatan Jagakarsa, Jakarta Selatan (Gambar 1). Pelaksanaan kegiatan PKM ini diawali koordinasi dengan pihak SMKN 63, terkait materi yang dibutuhkan SMKN 63 bagi peningkatan penerapan program Adiwiyata. Kemudian Tim Pengabdian dan SMKN 63 menyusun jadwal berdasarkan kesepakatan bersama dan menentukan bagian sekolah yang akan dirancang, yaitu taman sudut di halaman depan sekolah (Gambar 2)

\section{Pelaksanaan Kegiatan dan Analisis Hasil Kegiatan}

Langkah awal yang dilakukan oleh tim pengabdian setelah melakukan sosialisasi kepada 20 orang peserta PKM, terdiri dari 5 orang guru dan 15 orang siswa. Setelah itu, dilanjutkan dengan pelatihan pembuatan rancangan lanskap. Pada saat pelatihan, peserta dibagi dalam empat kelompok dan tiap dua kelompok mendapat pendampingan dari seorang fasilitator (dosen dari jurusan Arsitektur Lanskap). Selesai pelatihan, setiap kelompok mendapat kesempatan untuk melakukan presentasi. Hasil desain yang terbaik, kemudian disempurnakan oleh dosen penyuluh dan diserahkan pada pihak sekolah. Kemudian

Tabel 6 Rubrik nilai lembar observasi (modifikasi dari Rohaman \& Lusiyana 2017)

\begin{tabular}{lc}
\hline Nilai & Skor \\
\hline Kurang (K) & $1-4$ \\
Cukup (C) & $5-8$ \\
Baik (B) & $9-12$ \\
\hline
\end{tabular}

Tabel 5 Lembar observasi diskusi pada sosialisasi dan pelatihan

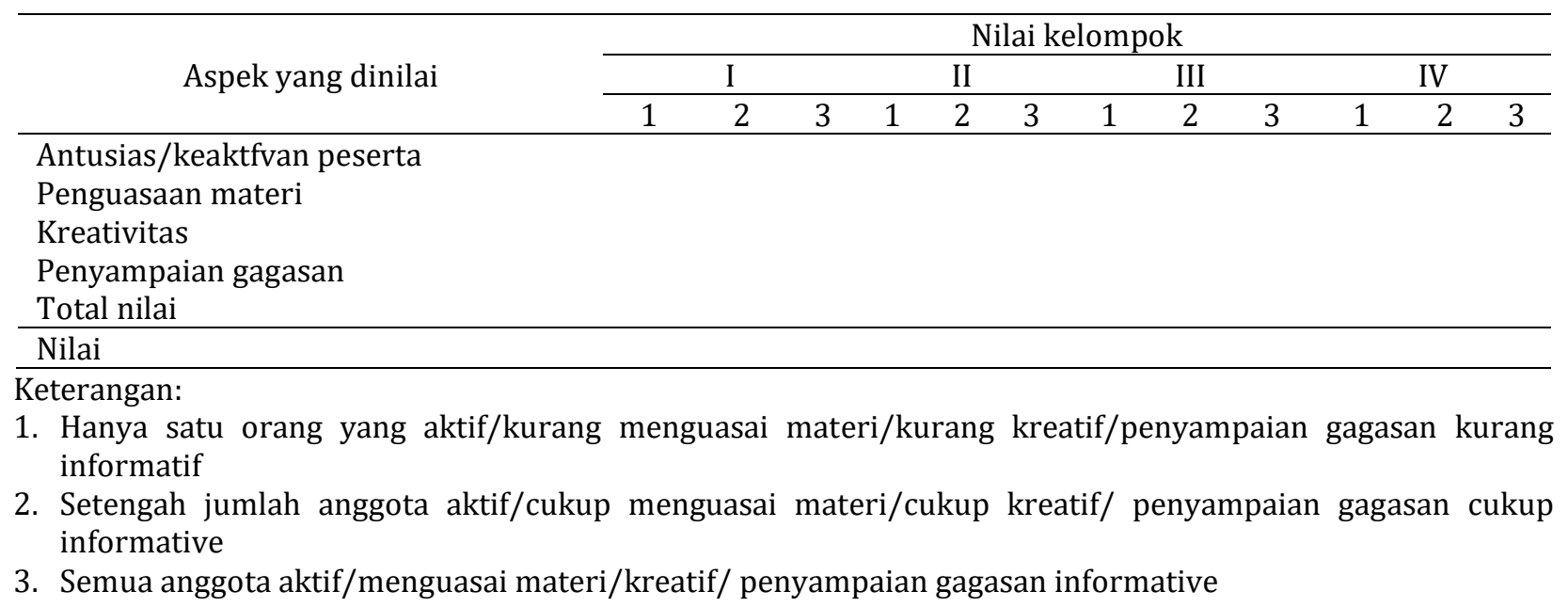




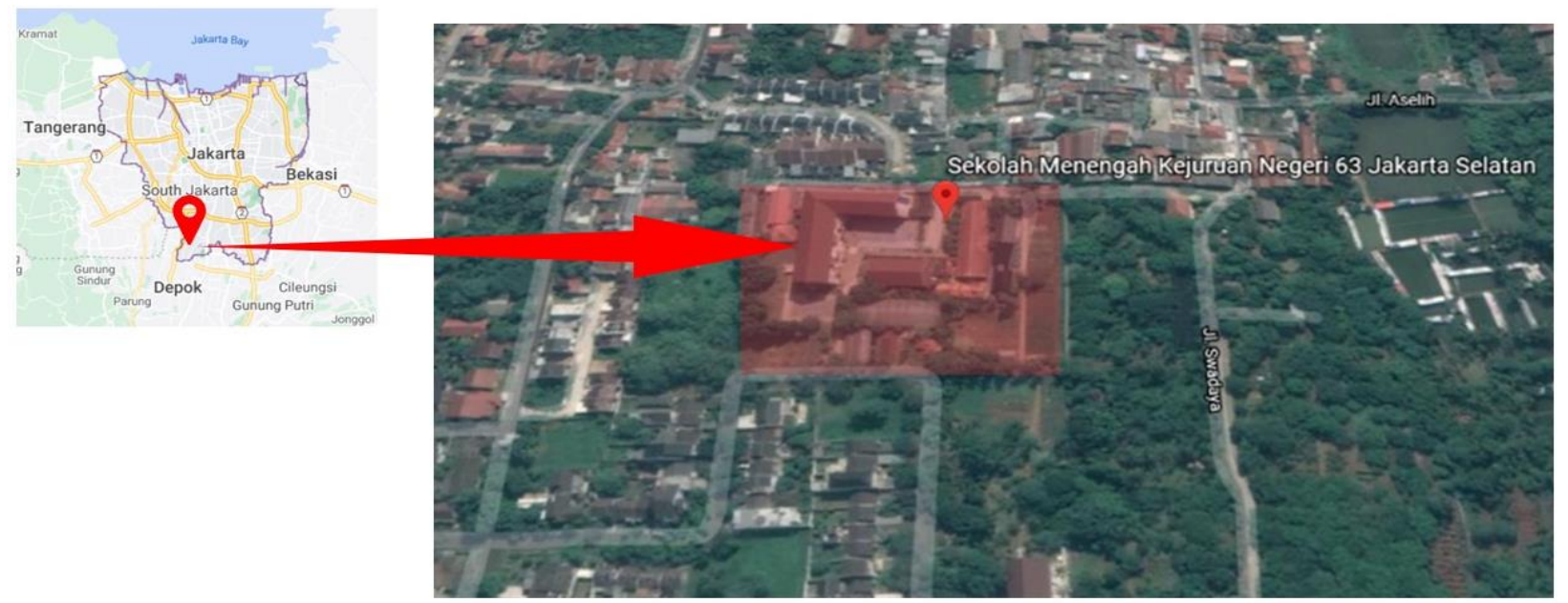

Sumber: Google earth, diunduh 09 februari 2021.

Gambar 1 Peta lokasi SMKN 63 Jakarta.

dilakukan pengukuran terhadap kegiatan sosialisasi dan pelatihan untuk melihat sejauh mana kegiatan bermanfaat bagi peserta, dengan memberikan kuisioner kepada peserta PKM. Pelaksanaan sosialisasi dan pelatihan dapat dilihat pada Gambar 3. Hasil desain yang telah disempurnakan dapat dilihat pada Gambar 4 . Hasil pengukuran dapat dilihat pada Tabel 7, 8, dan 9.

Langkah berikutnya dilakukan pengukuran terhadap sikap/tanggapan peserta pada saat sosialisasi dan pelatihan dilaksanakan. Hasil dari pengisian lembar observasi yang dilakukan oleh tim PKM dapat dilihat pada Tabel 10. Berdasarkan hasil observasi yang dilakukan pada saat sosialisasi dan pelatihan perancangan lanskap sekolah terlihat bahwa untuk aspek penguasaan materi, kreativitas, dan penyampaian gagasan rata-rata setiap kelompok masuk kategori C (cukup), namun untuk aspek antusias/keaktifan peserta, setiap kelompok masuk dalam kategori B (baik).

\section{Kendala yang Dihadapi}

Mengingat peserta program pengabdian yang terdiri dari guru dan siswa dengan latar belakang pengetahuan merancang yang relatif masih kurang, menyebabkan penyampaian materi sosialisasi harus dilakukan secara bertahap. Selain itu, untuk mempermudah pemahaman, maka diperbanyak diskusi. Demikian juga yang dilakukan pada saat dilakukan pelatihan. Lokasi dari area ruang luar sekolah yang dipilih untuk dijadikan lokasi yang akan dirancang adalah area yang tidak terlalu membutuhkan kajian kebutuhan yang kompleks. Pendampingan secara intensif juga dilakukan pada setiap kelompok

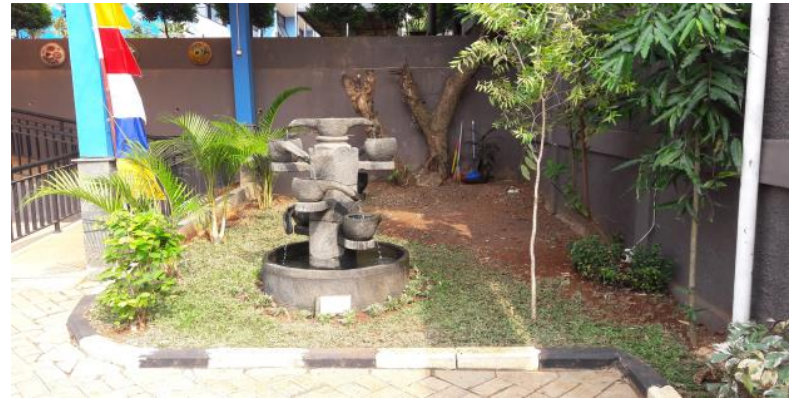

Sumber: Dokumentasi pribadi 2019

Gambar 2 Kondisi eksisting lokasi SMKN 63 Jakarta.

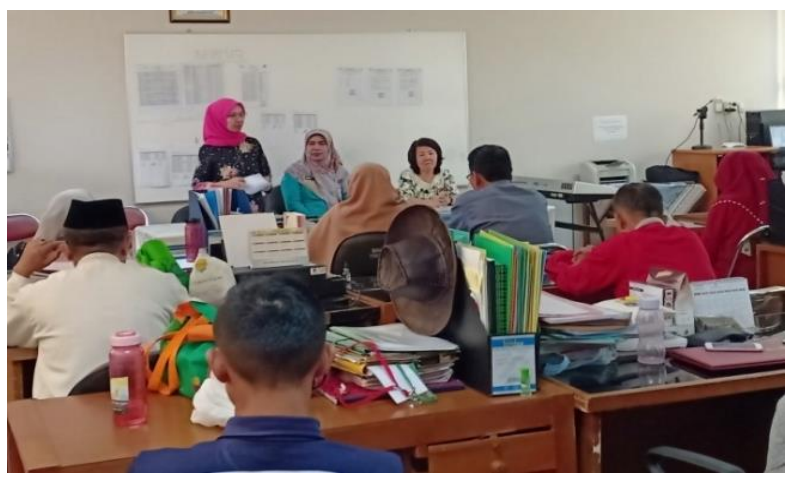

a

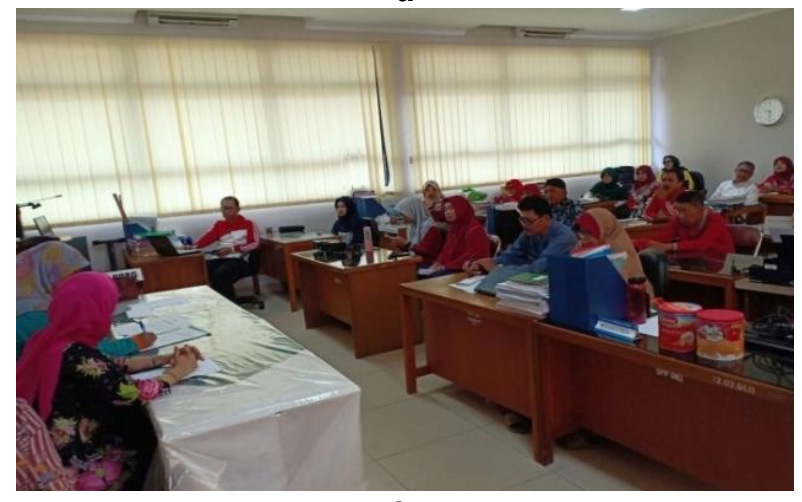

b

Gambar 3 a dan b Sosialisasi materi perancangan lanskap sekolah. 


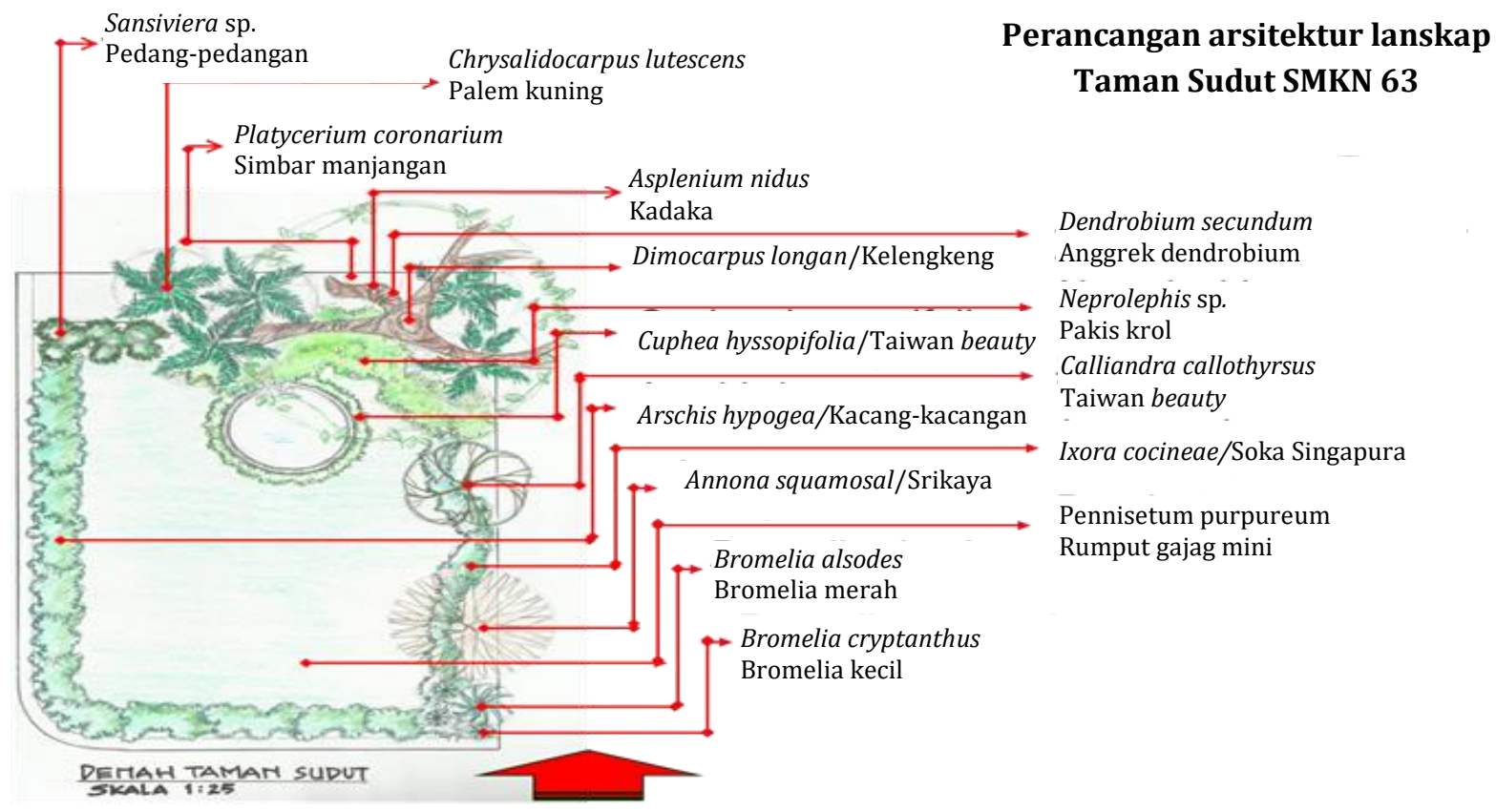

Gambar 4 Hasil rancangan lanskap pada taman sudut halaman depan SMKN 63.

Tabel 7 Nilai manfaat bagi peningkatan kualitas sarana dan prasarana ruang luar sekolah (lebih fungsional dan estetis)

\begin{tabular}{lccr}
\hline Pilihan jawaban & Frekuensi & $\begin{array}{c}\text { Persentase } \\
(\%)\end{array}$ & Nilai \\
\hline Sangat setuju & 8 & 40 & 40 \\
Setuju & 9 & 45 & 36 \\
Netral/ragu-ragu & 2 & 5 & 6 \\
Tidak setuju & 1 & 10 & 2 \\
Sangat tidak & 0 & 0 & 0 \\
setuju & 20 & 100 & 84 \\
\hline Jumlah & & & \\
\hline
\end{tabular}

Total nilai: 84 (katagori sangat setuju)

Persentase nilai $=84: 100 \times 100 \%=84 \%$

Tabel 8 Nilai manfaat bagi kegiatan pembelajaran

\begin{tabular}{lccr}
\hline Pilihan jawaban & Frekuensi & $\begin{array}{c}\text { Persentase } \\
(\%)\end{array}$ & Nilai \\
\hline Sangat setuju & 7 & 40 & 35 \\
Setuju & 8 & 35 & 32 \\
Netral/ragu-ragu & 3 & 10 & 6 \\
Tidak setuju & 2 & 10 & 4 \\
Sangat tidak & 1 & 5 & 1 \\
setuju & 20 & 100 & 78 \\
\hline Jumlah &
\end{tabular}

Total nilai: 78 (katagori setuju)

Persentase nilai $=78: 100 \times 100 \%=78 \%$

kerja. Ini dilakukan agar dapat diperoleh hasil rancangan yang optimal.

\section{Dampak dan Upaya Berkelanjutan}

Dampak dari kegiatan PKM ini terlihat baik. Ini terlihat ketika tim pengabdian melakukan
Tabel 9 Nilai manfaat bagi bagi pembinaan prilaku berbudaya lingkungan.

\begin{tabular}{lccr}
\hline Pilihan jawaban & Frekuensi & $\begin{array}{c}\text { Persentase } \\
(\%)\end{array}$ & Nilai \\
\hline Sangat setuju & 7 & 40 & 35 \\
Setuju & 8 & 35 & 32 \\
Netral/ragu-ragu & 2 & 10 & 6 \\
Tidak setuju & 2 & 10 & 4 \\
Sangat tidak & 1 & 5 & 1 \\
setuju & 20 & 100 & 78 \\
\hline Jumlah & & & \\
\hline
\end{tabular}

Total nilai: 78 (katagori setuju)

Persentase nilai $=78: 100 \times 100 \%=78 \%$

evaluasi, yaitu sebulan setelah pelaksanaan PKM. Hasil rancangan yang merupakan produk akhir dari salah satu kelompok peserta yang telah disempurnakan tim dan diserahkan ke pihak SMKN 63 telah diterapkan/dilaksanakan. Taman sudut di halaman depan SMKN 63 telah menjadi taman yang baru. Ini dilakukan warga sekolah secara bersama-sama 2 minggu setelah sosialisasi dan pelatihan yang diberikan tim. Selanjutnya, pihak SMKN 63 meminta tim pengabdian dapat melakukan pembinaan berkala terkait materi perancangan lanskap ruang luar sekolah agar penguasaan warga sekolah, terutama guru dapat lebih meningkat lagi. Dengan demikian, guru dapat membina siswa, terutama siswa dari program studi Lanskap dan Pertamanan, sehingga aktivitas perancangan lanskap ruang sekolah dapat dilakukan secara mandiri oleh warga sekolah secara optimal. Pihak SMKN 63 merasa keterampilan tersebut dapat mening- 
Tabel 10 Lembar observasi diskusi pada sosialisasi dan pelatihan

\begin{tabular}{lcccc}
\hline \multirow{2}{*}{ Aspek yang dinilai } & \multicolumn{4}{c}{ Nilai kelompok } \\
\cline { 2 - 5 } & I & II & III & IV \\
\hline Antusias/keaktivan peserta & $9 / \mathrm{B}$ & $9 / \mathrm{B}$ & $9 / \mathrm{B}$ & $9 / \mathrm{B}$ \\
Penguasaan materi & $7 / \mathrm{C}$ & $7 / \mathrm{C}$ & $6 / \mathrm{C}$ & $8 / \mathrm{C}$ \\
Kreativitas & $7 / \mathrm{C}$ & $6 / \mathrm{C}$ & $6 / \mathrm{C}$ & $7 / \mathrm{C}$ \\
Penyampaian gagasan & $6 / \mathrm{C}$ & $5 / \mathrm{C}$ & $4 / \mathrm{K}$ & $7 / \mathrm{C}$ \\
\hline Total nilai & 29 & 27 & 25 & 31 \\
\hline Nilai & $7 / \mathrm{C}$ & $6,75 / \mathrm{C}$ & $6,25 / \mathrm{C}$ & $7,75 / \mathrm{C}$ \\
\hline
\end{tabular}

katkan penerapan program Adiwiyata yang pada akhirnya prilaku berbudaya lingkungan dapat lebih melekat dan menjiwai siswa. Terkait dengan hal tersebut, telah disepakati pihak SMKN 63 dan tim pengabdian dari Jurusan Arsitektur Lanskap, FALTL-USAKTI akan melakukan kerjasama, agar pembinaan warga sekolah dapat dilaksanakan secara berkelanjutan.

\section{SIMPULAN}

Nilai manfaat yang dirasakan peserta dari materi sosialisasi dan pelatihan perancangan lanskap sekolah masuk dalam kategori setuju hingga sangat setuju. Kategori sangat setuju dipilih peserta atas nilai manfaat materi bagi peningkatan kualitas sarana dan prasarana ruang luar sekolah (lebih fungsional dan estetis). Kategori setuju dipilih peserta untuk nilai manfaat materi bagi kegiatan pembelajarandan nilai manfaat materi bagi pembinaan prilaku berbudaya lingkungan. Peserta memperlihatkan antusias dan keaktifan yang masuk dalam kategori baik, serta memperlihatkan penguasaan materi, kreatifitas, dan cara penyampai ide yang masuk dalam kategori cukup, sehingga masih perlu bimbingan. Untuk keberlanjutan dari kegiatan PKM ini, disepakati pihak SMKN 63 dan tim pengabdian dari Jurusan Arsitektur Lanskap, FALTL-USAKTI akan melakukan kerjasama, agar pembinaan terhadap warga sekolah dapat tetap dilaksanakan.

\section{DAFTAR PUSTAKA}

Agrotek Umpar. 2012. Elemen Pembentuk Lanskap. [Internet] [Diunduh pada: 5 Mei 2020]. Tersedia pada: http://agrotekumpar. blogspot.com/2011/12/elemen-pembentuklanskap.html.

Apriliyadi. 2019. SMKN 63 Jakarta, Satu-satunya Kebun Belajar SMK Pertanian di Jakarta.
[Internet]. [Diunduh pada: 7 Mei 2020]. Tersedia pada: http://psmk.kemdikbud. go.id/konten/4190/smkn-63-jakarta-satusatunya-kebun-belajar-smk-pertanian-dijakarta.

Budiaji W. 2013. Skala Pengukuran dan Jumlah Respon Skala Likert. Jurnal Ilmu Pertanian Dan Perikanan. 2(2): 127-133.

Bahrudin MDF. 2017. Pelaksanaan Program Adiwiyata dalam Mendukung Pembentukan Karakter Peduli Lingkungandi SMA Negeri 4 Pandeglang. Jurnal Pendidikan Geografi. 17(1): 25-37.

Hidayati N. 2013. Perilaku Warga Sekolah dalam Program Adiwiyata diSMK Negeri 2 Semarang. Prosiding Seminar Nasional Pengelolaan Sumber Daya Alam dan Lingkungan. Hal 149154.

Janti S. 2014. Analisis Validitas dan Reliabilitas dengan Skala Likert terhadap Pengembangan $\mathrm{Si} / \mathrm{Ti}$ dalam Penentuan Pengambilan Keputusan Penerapan Strategic Planning pada Industri Garmen. Dalam: Prosiding Seminar Nasional Aplikasi Sains \& Teknologi (SNAST). Yogyakarta (ID). Hal 64-69.

Krajhanz J. 2010. Environmental and Pro Environmental Behaviour. School and Health Journal. 21: 251-274.

Kamarullah, Nafsiatun, Hendri MI, Widiyantoro A. 2019. Peningkatan Perilaku Peduli Hukum dan Lingkungan Melalui Program Kemitraan Masyarakat Peduli Hukum. Dinamisia Jurnal Pengabdian Kepada Masyarakat. 3(1): 1-6. https://doi.org/10.31849/dinamisia.v3i1.20 56

[KIP JS]. 2019. 16 Sekolah Raih Penghargaan Adiwiyata Tingkat Kota Jaksel. [Internet]. [Diunduh pada: 7 Mei 2020]. Tersedia pada: https://selatan.jakarta.go.id/news/2019/07/ 16-sekolah-raih-penghargaan-adiwiyatatingkat-kota-jaksel. 
Multimedia. 2015. 5 Prinsip Desain dan Contohnya. [Internet] [Diunduh pada: 8 Mei 2020]. Tersedia pada: https://web7crawler. wordpress.com/2015/12/01/5-prinsipdesain-dan-contohnya/

Nugraha RS, Sumardi, Hamdu G. 2017. Desain Pembelajaran Tematik Berbasis Outdoor Learning Di SD. Indonesian Journal of Primary Education. 1(1): 34-40. https://doi.org/10. 17509/ijpe.v1i1.7495

Puspawati P. 2009. Manajemen Pembelajaran Pengalaman Lapangan Bidang Studi Matematika Kelompok Belajar Paket A Nusa Indah di Kecamatan Bandar, Kabupaten Batang. Jurnal PNFI. 1(1): 83-101.

Rohaman F, Lusiyana A. 2017. Pengembangan Modul Praktikum Mandiri Sebagai Asesmen Keterampilan Proses Sains dan Keterampilan Sosial Mahasiswa. Jurnal Inovasi Pendidikan Fisika Dan Riset Ilmiah. 1(2): 47-56. https:// doi.org/10.30599/jipfri.v1i2.115

Syofian S, Setiyaningsih T, Syamsiah N. 2015. Otomatisasi Metode Penelitian Skala Likert Berbasis Web. Dalam: Prosiding Seminar Nasional Sains dan Teknologi. Jakarta (ID): Universitas Muhammadiyah Jakarta.
Santiningtyas K. 2012. Pengaruh Outdoor Learning Berbasis Inkuiri terhadap Hasil Belajar Siswa Materi Ekosistem. [Skripsi]. Semarang (ID): Universitas Negeri Semarang.

Safitri OI, Retnoningsih A, Irsadi A. 2014. Penerapan Outdoor Learning Process (OLP) Menggunakan Papan Klasifikasi pada Materi Klasifikasi Tumbuhan. Unnes Journal of Biology Education. 3(1): 61-68.

Sidauruk T, Suriani M, Restu. 2013. Profil Perilaku Lingkungan Hidup Siswa SMA Negeri di Kota Medan. Jurnal Pendidikan Ilmu-ilmu Sosial. 5(1): 68-80. https://doi.org/10. 24114/jupiis.v5i1.539

Simonds JO, Starke WB. 2006. Landscape Architecture: A Manual of Environment Planning and Design. New York: McGraw-Hill Book Co.

Amirin TM. 2010. Skala Likert: Penggunaannya dan Analisis Datanya. [Internet]. [Diunduh 7 Mei 2020]. Tersedia pada: http:// tatangmanguny.wordpress.com

Widiyaningrum P, Lisdiyana, Purwantoyo E. 2015. Evaluasi Partisipasi Siswa dalam Pengelolaan Sampah untuk Mendukung Program Sekolah Adiwiyata. Indonesian Journal of Conservation. 4(1): 74-82. 